\title{
Optical coherence tomography angiography in pituitary tumor
}

Figure 1 Visual field test
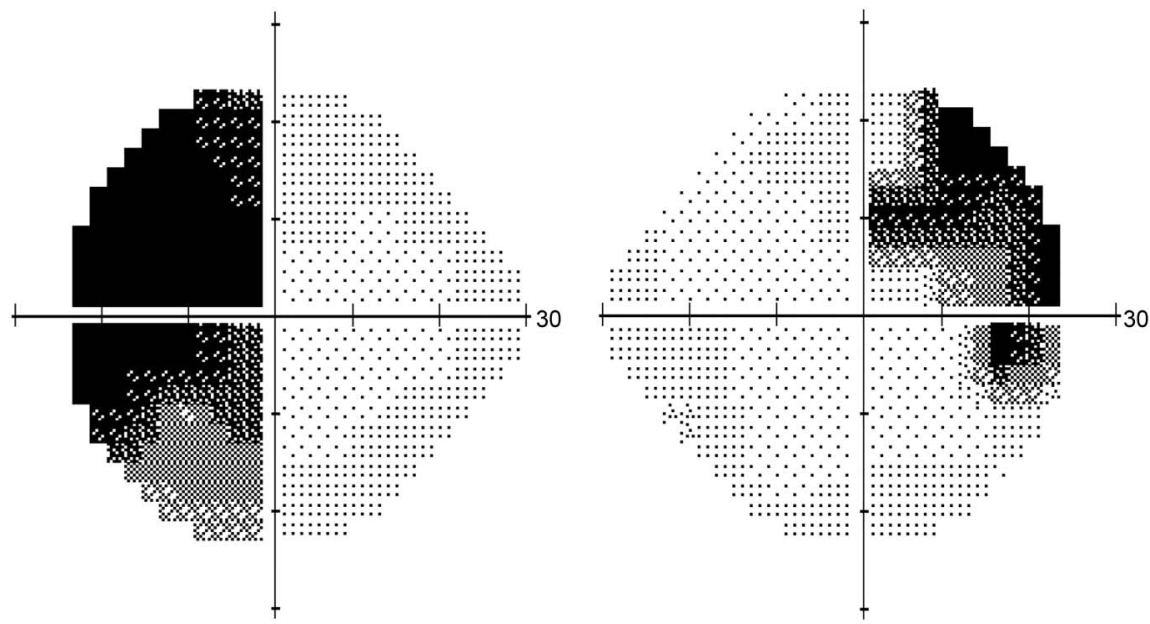

Asymmetric bitemporal hemianopia.

A 32-year-old man with a pituitary tumor had bitemporal hemianopia (figure 1). Peripapillary retinal nerve fiber layer (RNFL) in optical coherence tomography (OCT) was reduced, which corresponded to visual field defects. OCT angiography showed a dropout of capillaries and correlated well with RNFL loss in the OCT (figure 2). Compressive optic neuropathy may be associated with loss of the retinal ganglion cell layer and impaired peripapillary retinal perfusion. OCT angiography may be helpful to detect various optic neuropathies and in analyzing the vascular status of the optic nerve head and RNFL. ${ }^{1}$

Figure 2 Optical coherence tomography findings

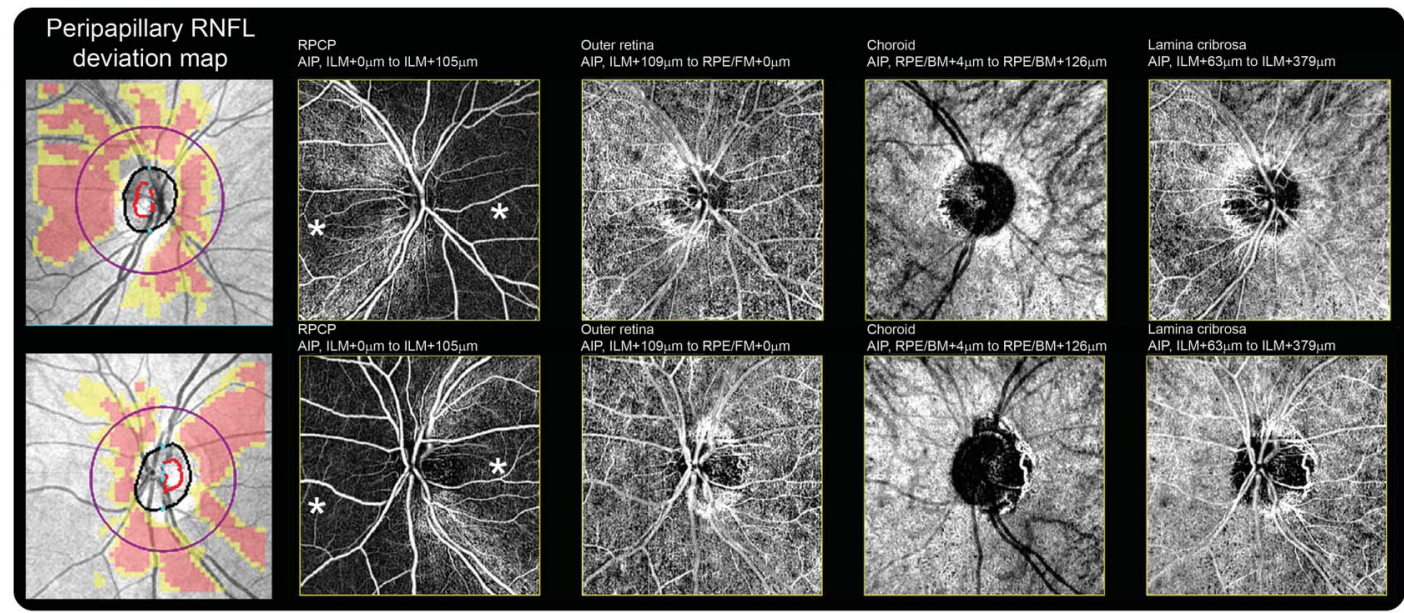

Thinning of peripapillary retinal nerve fiber layer (RNFL) was shown in the deviation map (color column). Although deep capillary networks including outer retina, choroid, and lamina cribrosa are relatively intact, a density of inner capillaries decreased significantly (asterisks). AIP = average intensity projection; ILM = internal limiting membrane; RPCP = radial peripapillary capillary plexus. 
Kun Hae Kim, MD, Ungsoo Samuel Kim, MD, PhD

From Kim's Eye Hospital (K.H.K., U.S.K.), Seoul; and Department of Ophthalmology (U.S.K.), Konyang University College of Medicine, Daejeon, Korea.

Author contributions: Dr. Kun Hae Kim: critical revision of the manuscript, analysis and interpretation. Prof. Ungsoo Samuel Kim: study concept and design, acquisition of data, analysis and interpretation.

Study funding: No targeted funding reported.

Disclosure: The authors report no disclosures relevant to the manuscript. Go to Neurology.org for full disclosures.

Correspondence to Dr. U.S. Kim: ungsookim@kimeye.com

1. Ghasemi Falavarjani K, Tian JJ, Akil H, Garcia GA, Sadda SR, Sadun AA. Swept-source optical coherence tomography angiography of the optic disk in optic neuropathy. Retina 2016;36(suppl 1):S168-S177.

\section{WriteClick ${ }^{\circledR}$ rapid online correspondence}

The editors encourage comments about recent articles through WriteClick:

Go to Neurology.org and click on the "WriteClick" tab at the top of the page. Responses will be posted within 72 hours of submission.

Before using WriteClick, remember the following:

- WriteClick is restricted to comments about studies published in Neurology within the last eight weeks

- Read previously posted comments; redundant comments will not be posted

- Your submission must be 200 words or less and have a maximum of five references; reference one must be the article on which you are commenting

- You can include a maximum of five authors (including yourself)

\section{Discover Altmetrics}

See real-time downloads and online activity for articles!

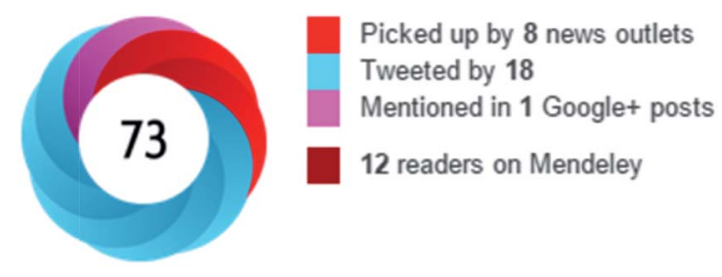

See more details

Authors and readers alike can view real-time data on articles including downloads and online activity across multiple sources. Click on the "Article Metrics" link in the right column of an article for details. To learn more about article metrics visit http://www.neurology.org/site/misc/article_usage.xhtml. 


\section{Neurology}

\section{Optical coherence tomography angiography in pituitary tumor \\ Kun Hae Kim and Ungsoo Samuel Kim \\ Neurology 2017;89;1307-1308 \\ DOI 10.1212/WNL.0000000000004397}

This information is current as of September 18, 2017

\section{Updated Information \&} Services

References

Subspecialty Collections

Permissions \& Licensing

Reprints including high resolution figures, can be found at: http://n.neurology.org/content/89/12/1307.full

This article cites 1 articles, 0 of which you can access for free at: http://n.neurology.org/content/89/12/1307.full\#ref-list-1

This article, along with others on similar topics, appears in the following collection(s):

All Imaging

http://n.neurology.org/cgi/collection/all_imaging

Optic nerve

http://n.neurology.org/cgi/collection/optic_nerve

Visual loss

http://n.neurology.org/cgi/collection/visual_loss

Information about reproducing this article in parts (figures,tables) or in its entirety can be found online at:

http://www.neurology.org/about/about_the_journal\#permissions

Information about ordering reprints can be found online:

http://n.neurology.org/subscribers/advertise

Neurology $®$ is the official journal of the American Academy of Neurology. Published continuously since 1951, it is now a weekly with 48 issues per year. Copyright (O 2017 American Academy of Neurology. All rights reserved. Print ISSN: 0028-3878. Online ISSN: 1526-632X.

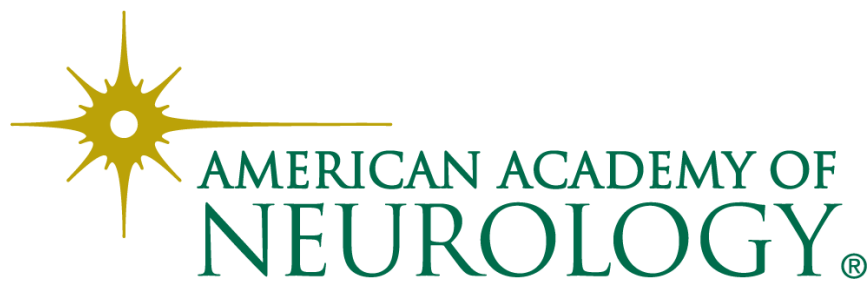

